\title{
Social Media and other Channels of Communication in Municipality Environment - Case Study of Hradec Kralove Region
}

\author{
Libuše SVOBODOVÁ ${ }^{1, *}$, Dorota BEDNARSKA-OLEJNICZAK ${ }^{2}$ and Jaroslava DITTRICHOVÁ ${ }^{1}$ \\ 1 University of Hradec Králové, Hradec Králové, Czech Republic; libuse.svobodova@uhk.cz, \\ jaroslava.dittrichova@uhk.cz \\ 2 Wroclaw University of Economics and Business, Wroclaw, Poland; dorota.olejniczak@ue.wroc.pl \\ * Correspondence: libuse.svobodova@uhk.cz
}

\begin{abstract}
The article deals with the ways of municipality communication with their citizens through selected social networks and other channels. Communication via the social network can offer better service, better communication and faster response that are printed sources. The cities were selected in the Hradec Králové region in the Czech Republic. Size of the cities is from 1,000 citizens to 5,000 and from 5,001 citizens to 10,000. Introduction and the second part deals with methods of communication and forms of how cities can get to the citizen and presents various social media. The main part of the article focus on the analysis of the websites and management of the social media that cities use and the other channels that the municipalities offer to the citizen for possible communication. It was found that smaller municipalities use social media less than the larger ones. Facebook is the most often used social media. Most of the cities use one social network. Web pages, newsletters and application are the next most often used channels for communication with citizens.
\end{abstract}

Keywords: application; municipality; social media; usage

JEL Classification: H00; O35; R10

\section{Introduction}

With the advancement of information technology society generally establishes itself from the traditional ways of communication to the modern one. New trends had to be adapted and offered by municipalities to its citizens. Municipalities make use of the possibility of remote control via websites and social networks. It is necessary to be able to correctly and secure offer and provide information to citizens in this information space.

Web sites are still the most widely used information tool for municipalities and cities at present time not only in the Czech Republic. Regions, cities, and the vast majority of municipalities make full use of web sites and consider them an inseparable part of the structure of their information systems. Websites allow direct information transfer, image building, relationships and advertisement serving. Municipalities have an obligation to use the Internet to the extent stipulated by law. However, the Internet now offers a wealth of opportunities to municipalities that they can use to support their activities. Towns and municipalities' websites should meet the basic three functions: Informative (static communication), Interactive (dynamic communication) and Presentation.

The paper focuses on social networks used in municipalities and focuses on the other ways of communication with citizens. The citizen of the municipality should be informed via social networks about all the important opportunities that they do in their municipality. Communication through social networks is significantly faster in this manner than in the printed form.

\subsection{Analysis of sources from Web of Science on municipality and social media}

The analysis of keywords connected with municipality and social media on Web of Science was done 24th of October 2019. Into search engine was put "municipality“ and „social media“. There were founded 151 articles focused on the selected topic. The biggest number of published articles were 44 in 
2018, 34 in 2017 and 27 in 2016. In 2019 were included into database 14 published articles. 116 were articles in journals, 33 proceedings paper 16 book chapters and others. Most of the articles were put on the information science and library science, public administration, computer science and information systems, communication and 22 in business economics etc. All research areas according to Web of Science are presented in fig. 1.

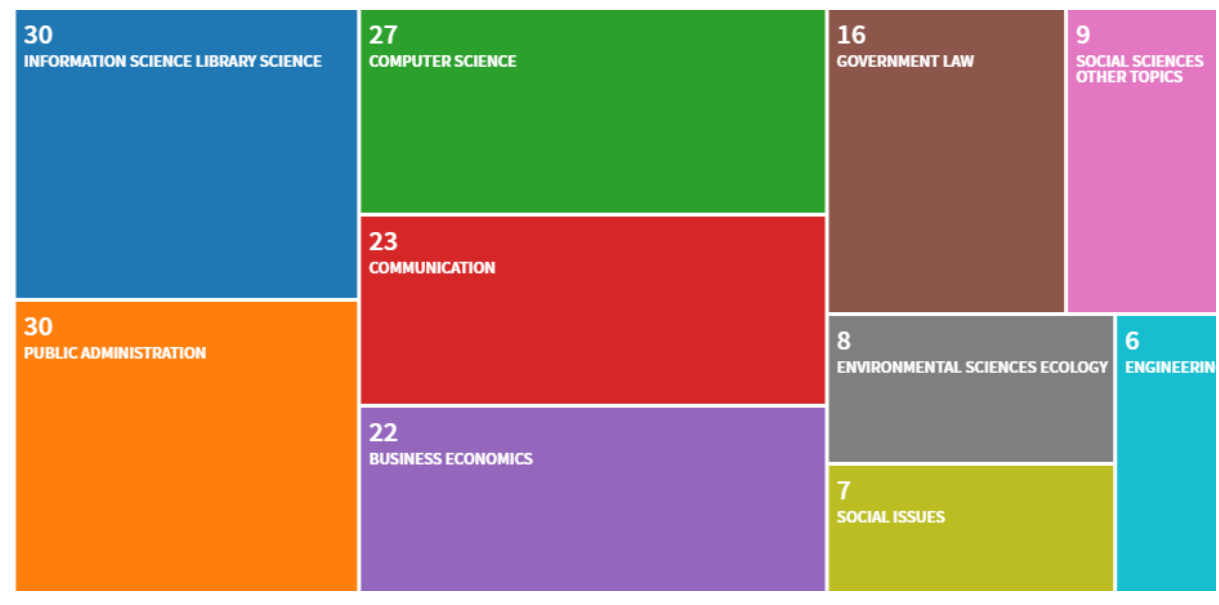

Figure 1. Research areas, according to Web of Science.

The biggest number in countries/regions were in Europe or in USA. The statistics won Spain with 24 articles. Detailed statistics are presented in fig. 2. In the Czech Republic were published 6 articles included in Web of Science with selected topic. Four articles are papers from Svobodová (Svobodová et.al. 2019; Svobodová 2017; Svobodová and Dittrichová 2016; Svobodová and Hedvičáková 2016). There is still possibility and space to publish articles with connected topic municipalities and use of social media to communicate with their citizens.

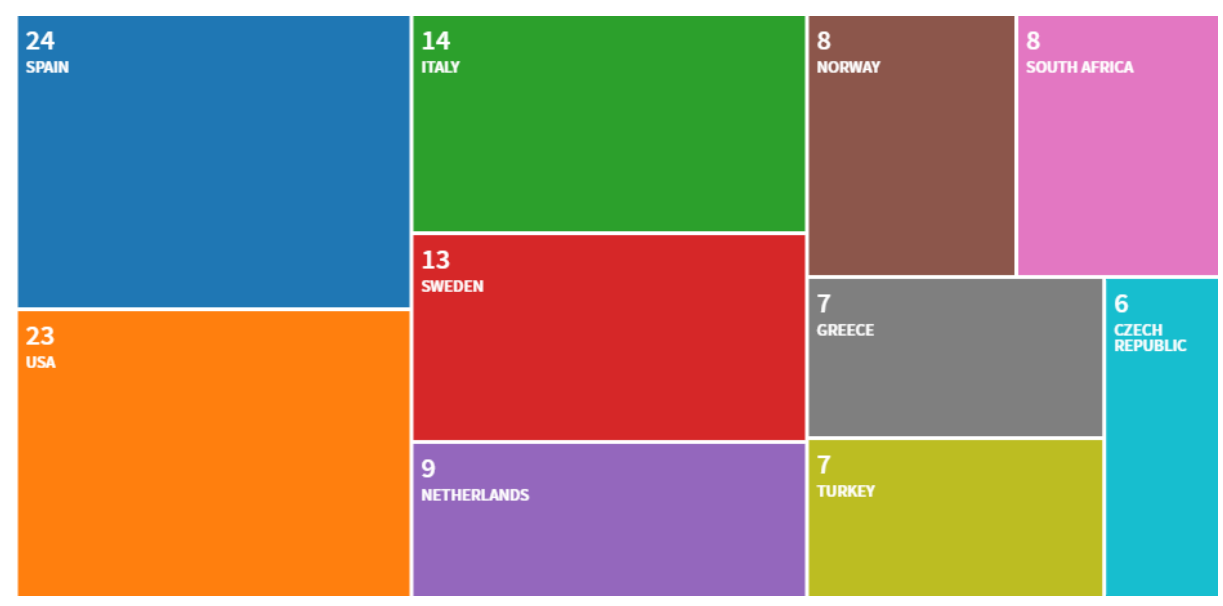

Figure 2. Countries/regions, according to Web of Science.

From VOSviewer were done next statistics according to most often published and cited authors on the selected topics. Into selection were put authors that have 4 and more publication and there were analysed their citations. The biggest number of publication have Bonsón et al. (2012) with highest number of citations. On the next positions is Royo with 5 documents and 414 citations and Lev-On with 5 documents and 30 citations. All other authors have 4 publications. Gesuele gained 21 citation, Rodriguez Bolivar 12 and 6 citations gained Klefodimos, Lappas and Triantafillidou. Authors that have 4 and more publication are presented in the connection with citations in fig. 3. 


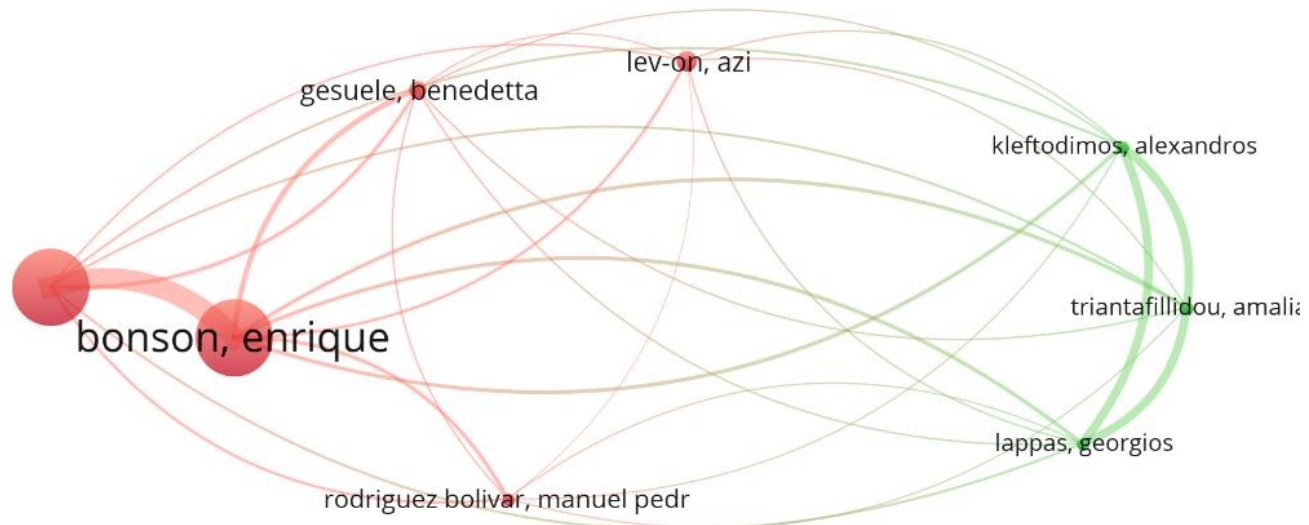

Figure 3. Authors with 4 and more publication on selected topic and citations, based on VOSviewer and Web of Science.

The most often cited article was Bonsón (2012) with 300 citations according to WoS. SandovalAlmazan and Gil-Garcia (2012) are with 114 citations placed on the second position. Bonsón et al. (2015) is placed also on the third position with 88 citations. On the next positions are Agostino (2013) and Sobaci and Karkin (2013) with 63 and 43 citations.

The most often used keywords were the last monitored issue. Minimum number of occurrences of a keyword was set as 10 . Of 710 keywords, 21 meet thresholds. There were founded 4 clusters of the keywords.

- Cluster 1 - communication, governance, internet, local government, management, social media, twitter.

- Cluster 2 - adoption, citizens, engagement, impact, municipalities, participation, social media use.

- Cluster 3 - e-government, facebook, information, transparency, trust, web 2.0.

- Cluster 4-e-participation.

The most often used keywords that also have the biggest link with this topic were:

- $\quad$ social media -88

- e-government - 39

- municipalities -31

- participation - 25

- $\quad$ adoption -24

- transparency -24

- facebook -24

Remaining keywords gained 19 points and less.

A new trend in online communication to increase the attractiveness of the municipality in the Moravian-Silesian Region was written by Klepek (2014). The impact of social media in the local government of the Spanish municipalities was analyzed by Criado and Francisco (2015). Social media in Smart City were addressed in the Mexican Communities (Sandoval-Almazan et al. 2012). Social media as the interactivity of municipal citizens in the management of American cities was solved by Mossberger et al. (2013). Italy also focused (Agostino 2013) on the use of social media to attract citizens in the municipalities.

\section{Methodology and Goal}

The paper deals with communication between cities and citizens via social networks and other channels of communication. In recent years, this topic is very actual, but in the Czech environment in some towns it is still almost unexplored area. The main goal of the research is to find out how officials communicate with citizens through social networks and through what social networks they 
communicate and what other communication channels do they offer. In the results it will be analyzed through which networks municipalities communicate and on how many social networks are cities active. Furthermore will be analyzed, what other possibilities the municipalities offer for the mentioned communication with citizens.

Secondary sources were used in the first part of the article. Primary sources were used in the part with results of the research.

\section{Conceptual framework of the research}

The conceptual framework of the paper was developed into methodological bases and procedures. The course of methodology is outlined in the following diagram, fig 4 .

Selection of

respondents

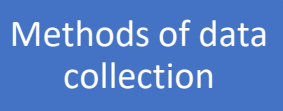

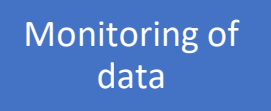

Analysis and evaluation

Figure 4. Methodology of research.

\section{- $\quad$ Selection of respondents}

The selection of a sample of respondents is the next phase. The Hradec Králové Region has 551,089 inhabitants and 448 municipalities. The research included a set of towns in the Hradec Králové Region in two samples. The first sample was determined by population, from 1000 to 5000 inhabitants and in the second sample the population threshold was set from 5001 to 10000 inhabitants. The first sample has 56 cities and the second sample has 14 cities. A total of 70 cities were surveyed. These two samples were used to examine in detail the social networks and other forms of communication that cities use. (Czech Statistical Office 2019)

\section{- Methods of data collection}

The accuracy and quality of the obtained data are significantly influenced by data collection methods. The data were collected by observation, when the data was collected by visiting of the official websites and profiles of municipalities and in the Hradec Králové Region on social networks, namely on Facebook, Twitter, YouTube and Instagram during March 2019. Observation is an indirect data collection tool that does not require direct contact with the respondent. Websites and other communication channels like application, newsletters etc. were also observed and analyzed. In terms of the methods used, quantitative research was applied in the research.

\section{- $\quad$ Monitoring of data}

The primary research consisted of monitoring the use of social networks and other forms of communication by selected Czech towns, which was carried out by means of observation. The data were observed from March 1, 2019 to March 31, 2019. In the first part it was examined which towns belong to two samples according to their population. Furthermore, it was examined whether municipalities refer to social net-works through websites and which of the social networks surveyed are used by municipalities and what other forms do they offer to citizens for communication.

- Analysis and evaluation

The choice of the method of data analysis depended on the main objective of the whole research, which was to evaluate the use of social networks and other forms of communication in cities in the Hradec Kralove region, namely on two samples. The social networks examined included Facebook, Twitter, Instagram, Linkedln, Youtube and web sites and applications for mobile devices and other forms of communication were evaluated. Data were signed into tables. Graphs were used for better visualization of data. 


\section{Use of Social Media and Communication Channels in Municipalities}

\subsection{The main communication channels in the municipalities}

Communication channels (networks) differ in their speed, cost, number of respondents, efficiency, etc. It also depends on the citizens that we want to address with the given message or information. It is also important what goals we want to achieve, because each communication channel has its advantages and disadvantages.

Communication channels that are the most often used between municipalities and citizens are:

- Internet - web pages and social media,

- boards,

- radio,

- meetings and consultations,

- newsletters or bulletins,

- public relations,

- fairs or exhibitions,

- conferences,

- deliberations,

- emails to residents,

- others.

\subsection{Social media and social network}

Boyd and Ellison (2007) define social network sites as web-based services that allow individuals to (1) construct a public or semi-public profile within a bounded system, (2) articulate a list of other users with whom they share a connection, and (3) view and traverse their list of connections and those made by others within the system.

Socialmediatoday (2019) presented the latest global statistics from social networks. Research mapped active users of the following social networks - Facebook, YouTube, Twitter, Instagram, Snapchat, Tumblr, Pinterest and LinkedIn.

Social media statistics (Emarsys 2019) show that there are 3.2 billion social media users worldwide, and this number is only growing. That equates to about $42 \%$ of the current population. In fact, people spend more than an hour and a half on social media every day! One of the reasons for this high usage of social media is because mobile possibilities for users are continually improving which makes it simpler by the day to access social media, no matter where you are. Most social media networks are also available as mobile apps or have been optimized for mobile browsing, making it easier for users to access their favorite sites while on the go.

Facebook has been shaping the social media landscape since its launch and is continually evolving to meet its user's needs. With over 2.32 billion active monthly users, Facebook remains the most widely used social media platform.

90.4\% of Millennials, $77.5 \%$ of Generation X, and $48.2 \%$ of Baby Boomers are active social media users. Users spend an average of 2 hours and 22 minutes per day on social networks and messaging. $91 \%$ of all social media users access social channels via mobile devices. (Oberlo 2019)

Most people use Facebook (with 2.3 billion monthly active users) and YouTube (with 1.9 billion). Then there are WhatsApp (1.6 billion users), Instagram and Wechat (1bn users), LinkedIn (610 million users), Weibo (600 users), Reddit (542 users), Twitter (330 million) and others (Brandwatch 2019).

\section{Results of the Analysis}

Use of social media, use of more social media and use of other channels for communication will be analyzed in the results of research.

After the analysis in the observed cities, it can be stated that larger cities use selected social networks more than smaller cities. Facebook, LinkedIn, Instagram and YouTube are the most often used in the communication, fig. 5 . Facebook shows the dominance in the use of social media by citizens. 


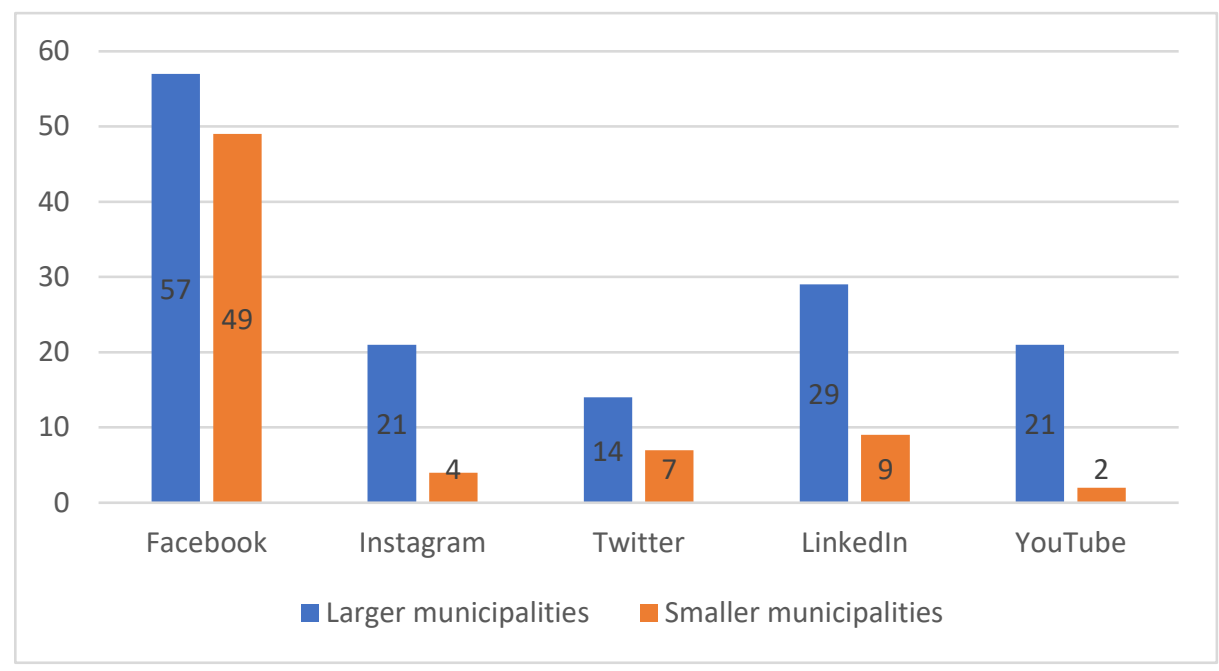

Figure 5. The social networks over which cities communicate, in $\%$.

The gained data show that cities use more social networks at the same time for communication. This can be seen in fig. 6 . The graph shows that $42 \%$ of smaller and $21 \%$ of larger municipalities do not use any social network to communicate with citizens. $44 \%$ and $21 \%$ use one network. There is also a significant difference in the use of two and three social networks. Two use only $7 \%$ smaller and $36 \%$ larger municipalities and three only $5 \%$ smaller and $21 \%$ larger. The results show that larger municipalities cumulate more social networks to inform citizens than smaller municipalities.

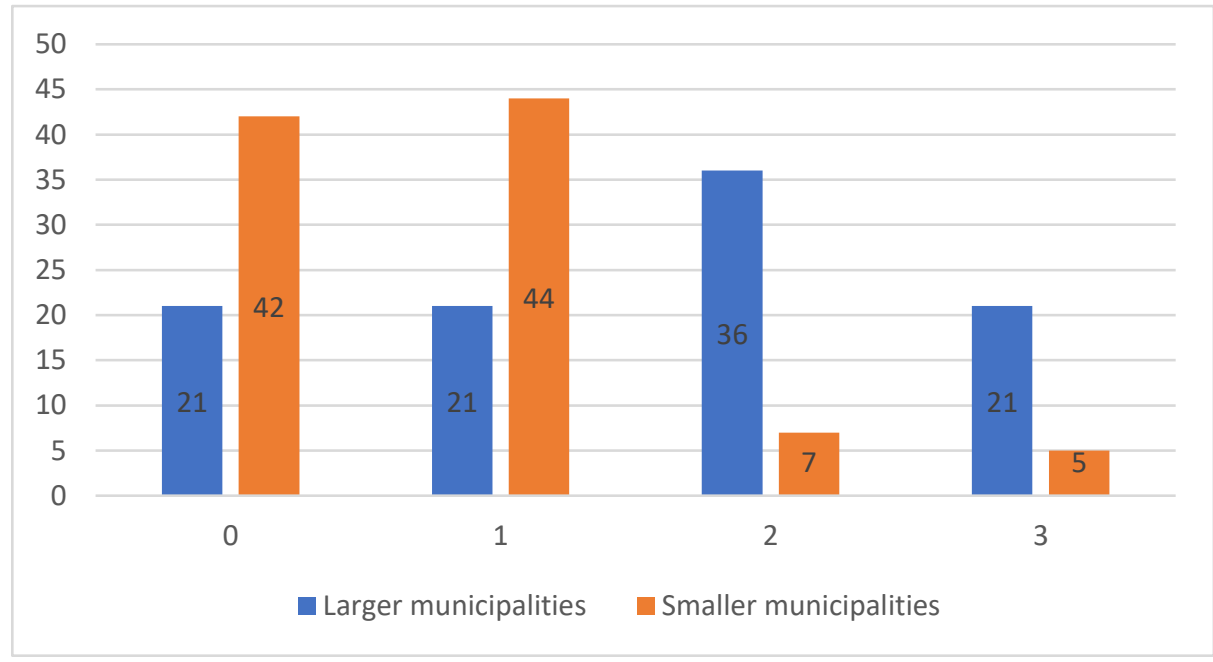

Figure 6. The number of social networks over which cities communicate, in $\%$.

It has been found that larger cities offer more other channels for communication than smaller cities, see fig. 7. Also application are a little bit less used in smaller cities than in larger. From our sample it was specifically $30 \%$ of small cities and $36 \%$ of large cities. The results of the research also show that smaller cities invested money for their own applications. All municipalities used web pages to inform citizens and similar results gained also newsletters that are still often used. Webcams recorded the highest difference between larger and smaller municipalities. 


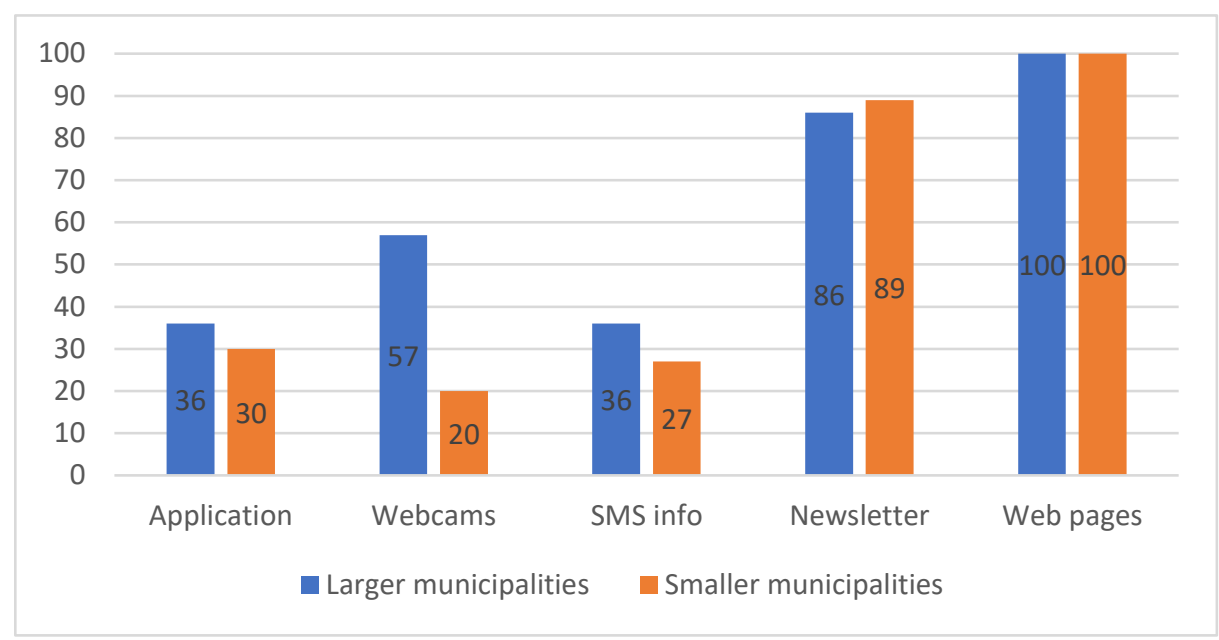

Figure 7. Other forms of communication which cities use, in $\%$.

\section{Conclusion, Discussion and Recommendations}

Just as the popularity of social networks is growing, their use by the public administration increases as well with the development of information technologies. Czech citizens and businesses can communicate with the government and local authorities through e-mail, they can browse their websites, where required forms can be found, downloaded or directly filled in and sent electronically. The current situation of the use of social networks by selected municipalities in the Hradec Králové region was based on the quantitative research and monitoring of data. Types of social networks used by the municipalities and whether municipalities use other forms how to communicate with citizens was monitored. Selected topic is not often solved by the Czech researches. The monitoring of the use of social networks by the Czech municipalities is not often and into deep mapped and presented to the auditorium. In the processing of the article it was necessary to focus on the detailed collection of data gained from the visit and observation of individual social networks, web pages, used applications and others.

The most often used social media is Facebook. YouTube, LinkedIn and Twitter have similar usage in the selected cities. Similar results were gained also in the previous research (Svobodová and Dittrichová 2016; Svobodová and Hedvičáková 2016). Most of the cities use one social network. Web pages, newsletters and application are the next most often used channels for communication with citizens. Important is to connect social networks with the www pages of municipalities. The links should be placed clearly on the first page.

It is possible to recommend to municipalities to do not use only web pages that citizens do not visit each day. Hot topics have to be communicated on social media, via application developed for municipality communication in the manner of network management system and communication. Those recommendation and channels of communication are mostly beneficial for the younger generation. Radio, boards and newsletters are mostly directed at elderly people or people that are not used to use advanced technologies and modern trends in the communication. Next solved issue may be the Involvement of Public Participation in the Czech Republic (see e.g. Bednarska-Olejniczak et. al. 2019).

The results (Bonson et. al. 2019) show that the majority of Andalusian local governments have an official corporate Twitter account with certain level of activity. There is no, however, a significant relationship between the population of a municipality and its citizen's engagement, and there is a significant negative relationship between audience and engagement and between activity and engagement. The findings of the study also show the particular media and content types generate higher engagement than others. In our sample is Twitter the least used social media in the selected cities. Our results also show that smaller municipalities use this type of communication less than larger municipalities. 
Acknowledgments: The paper is supported by the project SPEV 2020 at the Faculty of Informatics and Management of the University Hradec Kralove, Czech Republic. In addition, the authors thank Anna Borkovcova and Marek Zanker for help with the project.

\section{References}

Agostino Deborah. 2013. Using social media to engage citizens: A study of Italian municipalities. Public relations review: 30, 232-234. https://doi.org/10.1016/j.pubrev.2013.02.009

Bednarska-Olejniczak Dorota, Olejniczak Jaroslaw, and Svobodová Libuše. 2019. Towards a Smart and Sustainable City with the Involvement of Public Participation-The Case of Wroclaw. Sustainability: 11, 1-33. https://doi.org/10.3390/su11020332

Bonsón Enrique, Torres Lourdes, Royo Sonia, and Flores Francisco. 2012. Local e-government 2.0: Social media and corporate transparency in municipalities. Government information quarterly: 29, 123-132. https://doi.org/10.1016/j.giq.2011.10.001

Bonsón Enrique, Royo Sonia, and Ratkai Melinda. 2015. Citizens' engagement on local governments' Facebook sites. An empirical analysis: The impact of different media and content types in Western Europe. Government information quarterly: 32, 52-62. https://doi.org/10.1016/j.giq.2014.11.001

Bonsón Enrique, Perea David and Michaela Bednárová. 2019. Twitter as a tool for citizen engagement: An empirical study of the Andalusian municipalities. Government information quarterly: 36, pp. 480-489, https://doi.org/10.1016/j.giq.2019.03.001

Boyd M. Danah, and Ellison B. Nicole. 2007. Social Network Sites: Definition, History, and Scholarship. Journal of Computer-Mediated Communication: 13, 210-230. https://doi.org/10.1111/j.1083-6101.2007.00393.x

Brandwatch. 2019. 126 Amazing Social Media Statistics and Facts. Available online: https://www.brandwatch.com/blog/amazing-social-media-statistics-and-facts/\#section-2 (accessed on 20 January 2020).

Criado J. Ignacio, and Francisco Rojas-Martin. 2015.The impact of social media in local government Myths and realities in the Spanish case. IDP-internet law and politics: 20, 25-42. http://doi.org/10.7238/idp.v0i20.2581

Czech Statistical Office - population in the Královéhradecký Region by municipality as at 1 January 2019, Available online: https:/www.czso.cz/csu/czso/population-of-municipalities-iot924ie6k (accessed on 20 January 2020).

Emarsys. 2019. Top 5 Social Media Predictions for 2019. Available online: https://www.emarsys.com/resources/blog/top-5-social-media-predictions-2019/ (accessed on 20 January 2020).

Klepek Martin. 2014. New trends in online marketing communication as a tool for increasing attractiveness of municipalities in Moravian-Silesian region. Paper presented at 17th International Colloquium on Regional Sciences, Hustopece, Czech Republic, June 18-20, pp. 441-446. Available online: https://www.econ.muni.cz/do/econ/soubory/katedry/kres/4884317/48596005/056_2014.pdf (accessed on 20 January 2020).

Mistoprodeje. 2018. Do you know the latest known global facts and statistics from social networks?. Available online: https://www.mistoprodeje.cz/clanky/vyzkumy-a-jina-cisla/znate-nejnovejsi-znama-globalni-faktastatistiky-ze-socialnich-siti/ (accessed on 20 January 2020).

Mossberger Karen, Wu Yonghong, and Crawford Jared. 2013. Connecting citizens and local governments? Social media and interactivity in major US cities. Information science $\mathcal{E}$ library science: 30, 351-358. https://doi.org/10.1016/j.giq.2013.05.016

Oberlo. 2019. 10 Social Media Statistics You Need to Know in 2019. Available online: https://www.oberlo.com/blog/social-media-marketing-statistics (accessed on 20 January 2020).

Sandoval-Almazan Rodrigo, and Gil-Garcia J. Ramon. 2012. Are government internet portals evolving towards more interaction, participation, and collaboration? Revisiting the rhetoric of e-government among municipalities. Government information quarterly: 29, 72-81. https://doi.org/10.1016/j.giq.2011.09.004

Sobaci Z. Mehmet, and Karkin Naci. 2013. The use of twitter by mayors in Turkey: Tweets for better public services? Government information quarterly: 30, 417-425. https://doi.org/10.1016/j.giq.2013.05.014

Socialmediatoday. 2019. Social Media Statistics You Need to Know in 2019. Available online: https://www.socialmediatoday.com/news/10-social-media-statistics-you-need-to-know-in-2019infographic/559181/ (accessed on 20 January 2020). 
Svobodová Libuše, Olejniczak Jaroslaw, Bednarska-Olejniczak Dorota, and Dittrichová Jaroslava. 2019. Use of Web 2.0 and Social Networks by Regional Cities in the Czech Republic and in Poland. Paper presented at the 17th International Scientific Conference on Hradec Economic Days, Hradec Kralove, Czech Republic,
February
5-6,
pp.
382-393.
Available
online:

https://uni.uhk.cz/hed/site/assets/files/1073/proceedings_2019_2-1.pdf (accessed on 20 January 2020).

Svobodová Libuše. 2017. Social Networks and Web Pages Used by Regional Municipalities in the Czech Republic.

Paper presented at 14th European, Mediterranean, and Middle Eastern Conference, Coimbra, Portugal, September 7-8, pp. 210-218. Available online: https://link.springer.com/chapter/10.1007/978-3-319-659305_18 (accessed on 20 January 2020).

Svobodová Libuše, and Dittrichová Jaroslava. 2016. Utilization of social media in municipalities in the Czech Republic. Paper presented at the 19th international colloquim on regional sciences, Cejkovice, Czech Republic, June 15-17, pp. 824-831. Available online: https://is.muni.cz/do/econ/soubory/katedry/kres/4884317/Sbornik2016.pdf (accessed on 20 January 2020).

Svobodová Libuše, and Hedvičáková Martina. 2016. Internet and Social Networks as a Support for Communication in the Municipality Environment. Paper presented at the 28th International BusinessInformation-Management-Association, Seville, Spain, pp. 3600-3605. Avaliable online https://core.ac.uk/download/pdf/154346950.pdf (accessed on 20 January 2020). 